\title{
A study of how uncertainty emerges in the uncertainty-embedded innovation process
}

\author{
Sabrina Luthfa \\ sabrina.luthfa@hv.se | University West, 46186 Trollhättan, Sweden
}

\begin{abstract}
This paper aims to understand about how uncertainty emerges in the innovation process. Since uncertainty is embedded in the innovation process, to understand how uncertainty emerges in the process one needs to understand how innovation process unfolds over time. Since an innovation process involves various resource recombination activities occurring in several phases, to understand how innovation process unfolds one needs understand "how do various resource recombination activities occur over time for the creation of novelty?" This knowledge would enable us to understand the conditions under which vital activities of resource recombination can/cannot be undertaken and coordinated as well as would allow us to understand the underlying decisions made by the innovators for their efficient undertaking and coordination. This paper investigates the innovation process in two companies through performing qualitative study. The innovation processes are analysed in the light of a conceptual model developed based on the Dubois' (1994) End-product related activity structure model, Håkansson's (1987) "ARA model" and Goldratt's (1997) "Critical chain concept". The findings suggest that uncertainty emerges in the innovation process in a cycle of interaction with resource void, activity void and actors' limited cognition due to lack of knowledge, undue optimism, and rationally justified reason for disregarding information. Accordingly, a great deal of compromises is made while undertaking the activities.
\end{abstract}

Keywords. Uncertainty, Innovation Process, Activity Void, Resource Void and Actors' Limited Cognition.

Cite paper as: Luthfa, S., (2019). A study of how uncertainty emerges in the uncertainty-embedded innovation process, Journal of Innovation Management, www.open-jim.org, 7(1), 46-79. HANDLE: https://hdl.handle.net/10216/119830; DOI: https://doi.org/10.24840/2183-0606_007.001_0005 


\section{Introduction}

Companies execute innovation strategies to gain competitive edge over their competitors by creating novelty and to ensure survivability and sustainability in the often-changing market (Yamin et al., 1997; Porter and Stern, 2001). However, it is not easy to execute innovation strategy because the innovation process is embedded with uncertainty (Kirzner, 1979; Gartner, 1990; Fleming, 2001; Jalonen, 2011; Pavitt, 2013). Managers face different types of uncertainties along the innovation process, such as, technological, commercial, organizational, market, regulatory/institutional, social/political, acceptance/legitimacy, financial, timing, and behavioural uncertainties (Jalonen, 2011). Uncertainties affect the transformation of an idea into novelty (Kline and Rosenberg, 1986; Van de Ven et al., 1999) as a result, many promising ideas fail to be realized. Braeutigam's (1979) quote conveys how uncertainty is present in an innovation process: "Will an innovative effort result in an implementable technology, and if so, when? ... will the implementation of the technology be delayed by a regulatory authority, and if so, for how long? And finally, when the regulator permits the use of an innovation, what level of benefits will the firm ultimately receive? (p. 98)". Amid such uncertainties the organization that can manage this process efficiently has greater survivability and sustainability in the market (Dodgson, 2015).

There is ample of research in field of innovation studies which focused on the topic of uncertainty especially on the effects it creates on the innovation process (Damanpour, 1996; Rogers, 1983; Fleming, 2001; Ortt and Smits, 2006; York and Venkataraman, 2010). However, Fleming (2001) argued that "Despite this widespread acknowledgement of the importance of uncertainty, most research gives the topic brief consideration in route to other issues and little work has attempted to identify and empirically validate the causal sources of uncertainty" (p. 117). Jalonen (2011) also argued that in most of these studies the presence of uncertainty has been taken for granted as an independent variable having some specific effect on the process, and little is known about the causal sources of the uncertainty and how it manifests in the process. Although Jalonen (2011) categorised different sources of uncertainties based on an extensive literature review of 101 articles, he did not explain in which way they emerge in the process. Both Jalonen (2011) and Fleming (2001) argued that it is important to know the sources of uncertainties as well as how they manifest themselves in the process as this knowledge would enable practitioners avoiding the uncertainties thereby coordinating their innovation management activities efficiently. On the contrary to their view that uncertainty can be avoided in an innovation process by learning about its different sources, in a recent study Luthfa (2017) argued that uncertainty is unavoidable because of its embeddedness in the process. Based on the argument that uncertainty is embedded in the innovation process (Fleming, 2001; Rehn and Lindhal, 2011; Pavitt, 2013), she argued furthermore uncertainty is not only a factor affecting the process itself but also the outcome of the process (p. 23) and therefore one needs to be prepared to deal with those always during the undertaking of the process. However, there is little we know about how uncertainty manifests itself in the innovation process from the existing literature (Luthfa, 2017; Jalonen, 2011).

This paper argues that the knowledge about how uncertainties emerge in the innovation process would not only enable researchers to learn about the conditions under which uncertainties emerge in that process but also would enable researchers to know the conditions under which vital ac- 
tions for novelty creation can/cannot be undertaken and coordinated efficiently. As we know, innovation in an interactive process that entails various resource recombination activities and their efficient coordination (Schumpeter, 1934; Rogers, 1967, 1983; Richardson, 1972; Utterback and Abernathy, 1975; Rescher, 2000), thus when uncertainties emerge in the innovation process those affect the undertaking and coordination of those various resource recombination activities subsequently affect the novelty creation. Furthermore, the knowledge about the conditions under which vital actions can/cannot be undertaken and coordinated would enable researchers to understand how to manage those conditions most efficiently for the efficient coordination of the activities. Therefore, this paper aims to deepen our knowledge of how uncertainty emerges in the innovation process.

Based on the argument that uncertainty is not only a factor affecting the process itself but also the outcome of the process (Luthfa, 2017; p. 23) to understand how uncertainty emerges in the innovation process this paper argues that it is necessary to understand how the process itself unfolds over time; that is, how various [resource recombination] activities occur in several stages or phases over time (Schumpeter, 1934; Rogers, 1967, 1983; Richardson, 1972; Utterback and Abernathy, 1975; Rescher, 2000). Therefore, to fulfil the purpose of the study the following research question have been posed: How do various resource recombination activities occur over time for the creation of novelty?

This paper has been structured as follows. The literature review section reviews existing knowledge of uncertainties in relation to the innovation process and reveals the gap in our current knowledge. An uncertainty-embedded innovation process model has been developed in the theoretical framework section to illustrate and analyse how innovation process unfolds overs time as well as to explain how uncertainty manifests in the process. The methodology section discusses about the choice of the method, data collection and analysis technique. In the empirical section two stories of the innovation processes have been discussed. Finally, after the analysis of the processes a conclusion has been drawn, theoretical and managerial implications have been stated and suggestions are made for further research.

\section{Literature review}

\subsection{Innovation process and uncertainty in the innovation process}

According to the "process philosophy" (Rescher, 2000) any process implies a set of sequentially linked activities towards an end; an outcome (Richardson, 1972; Dubois, 1994). An innovation process is an integrated series of connected development of meaningful events or sequence of resource recombination activities where one ends and the other begins and finally a novelty is produced (Schumpeter, 1934; Rogers, 1967; Richardson, 1972; Dubois, 1994; Rescher, 2000). However, the end of a process is never the final end as it always paves the way for greater changes (Rescher, 2000). The temporality of an end of a process makes the end of the innovation process (novelty) a temporary solution as well as a unique one from what has been created before and what will be created afterwards. In this study novelty has been defined as something new, therefore unique and significantly improved from the earlier ones (Oslo manual, 2005) for both who creates it and who consumes it. Since novelties are new they are not identical 
to one another (Martinez-Ruiz, et al., 2011). The distinctiveness of the novelties makes it difficult for the innovators to know or to plan which activities to undertake in advance. No actor has precise knowledge about what resource recombination activities will bring that distinct solution. Under limited availability of knowledge actors experience uncertainty: a condition when actors' existing knowledge and prior experiences become inadequate or divergent from understanding what activities are required to take the next step or what outcome might come from those activities (cf. Knight, 1921; Reddy, 1996; Lenfle and Loch, 2010; Jalonen, 2011; Håkansson and Olsen, 2012). According to Lenfle and Loch (2010) the innovation process is like "proceeding in the dark" where one's theoretical knowledge is not necessarily enough to deal with the reality. According to Håkansson and Olsen (2012) the innovation process contains the "elements of exploration into the unknown, into the unexpected and quiet often also into the impossible, the irrational" (p.81). Under such conditions, actors respond to the way the stories of innovation unfold over time (Håkansson and Olsen, 2012). Since "way leads on to way" (Lundgren, 1995; p. 91) actors' response to the evolution of the innovation story can lead the entire innovation project onto a different trajectory from what has initially been anticipated (Lundgren, 1995; Håkansson and Olsen, 2012) and in this manner can create further uncertainty in the innovation process. Therefore, uncertainty also becomes an outcome of the innovation process; the outcome of the way the activities are undertaken and coordinated. Therefore, several researchers (e.g. Fleming, 2001; Lenfle and Loch, 2010; Jalonen, 2011; Rehn and Lindahl, 2012; Håkansson and Olsen, 2012) argue that innovation process is inherently uncertain meaning uncertainty is unavoidable in the process.

\subsection{Different types of uncertainty in the innovation process}

According to Galbraith (1977) a great deal of uncertainty exists about how to define the concept of uncertainty. Unlike risk, which is measurable (Knight, 1921), uncertainty cannot be measured (Galbratih, 1977; Jalonen, 2011) because it involves unstandardized operation or non-systematic activities (Utterback and Abernathy, 1975). An innovation process is both risky and uncertain. It is risky because it entails significant investment therefore entails significant cost (Gompers and Lerner, 2001; Eveleens, 2010; Muller, 2013; O'Sullivan, 2013) unless the outcome of the resource recombination process is widely accepted by the users (Rogers, 1967). It is uncertain because an innovator's knowledge or experience or resources is inadequate or unavailable or imperfect to steer those non-systematic resource recombination activities as well as to predict the final outcome of the process (Knight, 1921/2012; Galbraith, 1977; Daft and Lengel, 1986; Brashers, 2001; Håkansson and Olsen, 2012; Holmen and McKelvey, 2013).

The term "uncertainty" and its different types in relation to the innovation process has been discussed in several studies (e.g., McMullen and Shepherd, 2006; Bessant, 2008; Foster, 2010). Among those different types, technological uncertainty has been the most discussed one, because it is usually considered synonymous with technological invention (cf. Fleming, 2001; Jalonen, 2011). According to Fleming (2001) technological uncertainty is high when innovators try to recombine unfamiliar components. In contrast, technological uncertainty is low when innovators try to combine familiar components. The degree of technological uncertainty is inversely proportional to the degree of prior knowledge and experiences of handling familiar activities. High 
technological uncertainty may increase the likelihood of failure in comparison with low technological uncertainty but may increase the likelihood of creating radical innovation if managed efficiently (Dosi, 1982; Fleming, 2001).

Many studies have also emphasised regulatory/institutional uncertainty (Braeuitigam, 1979; Freel, 2005; Prieger, 2007; Bessant, 2008; York and Venkataraman, 2010) which has a significant impact on the innovation process. Regulatory uncertainty is created by the policy makers, who wield their power to prohibit, stimulate, monitor, and regulate activities in the innovation process (Freeman, 1974; Rogers, 1983; Nelson, 1993; Foster, 2010). Generally, policy makers adopt policies for supporting innovation but sometimes the same policy can become the source of uncertainty (Jalonen, 2011). For example, government policy encouraging the establishment of coal-based and nuclear power plant in Bangladesh to ensure power supply is threatening the possibility of innovation in the renewable energy sector. High regulatory uncertainty affects managers' ability to assess risk and opportunities thereby affect their ability to make the trade-offs necessary for investment in new technologies (Marcus, 1981). The fields of biotechnology, nanotechnology, and medical technology is especially affected by this type of regulatory uncertainty (Fleurke and Somsen, 2011).

Social and political uncertainty also create significant impact on the innovation process. Innovation process takes place in interaction among various actors such as business firms, individuals, and public and private institutions (Edquist and Hommen, 1999; Lundvall, 2007). The purpose of engaging in interaction with others is to gain access to different types of resources (technological, financial, immaterial) which are necessary for undertaking resource recombination activities, and to gain insider-ship in a foreign market to escape institutional uncertainty (Håkansson, et al., 2009). However, not always collaborating partners are willing to share resources such as intellectual property (IP) rights (Spencer, 2003) unless there is a great deal of trust among the actors. Unless rtsut is well established actors fear the loss of IP rights in the hand of opportunistic actors. Trust plays an important role in exchange relationship (Morgan and Hunt, 1994; Nooteboom, Berger and Noorderhaven, 1997; Das and Teng, 1998; Madhok, 2006). Institutional bodies like public and private funding agencies may not provide firms financial resources necessary for innovation (Kline and Rosenberg, 1986; Van de Ven et al., 1999; Gompers and Lerner, 2001; Powell et al., 2002; Håkansson and Waluszewski, 2002; Tidd and Besant, 2009; Muller, 2013; O'Sullivan, 2013). Under such circumstances, actors experience social and political uncertainty (e.g., Milliken, 1987; Holmen, 2001; McMullen and Sheferd, 2006; Ortt and Smits, 2006; Jalonen, 2011; Håkansson and Olsen, 2012; Luthfa, 2017).

One type of uncertainty leads to other types of uncertainties if not handled efficiently and timely. For example, regulatory uncertainty can block necessary technological, material, non-material (knowledge) and financial resource flows among actors thus can affect the resource recombination activities and finally can delay the production, introduction, and diffusion of a product to the market. Thus, regulatory uncertainty can lead to acceptance/legitimate and commercial uncertainty (Prieger, 2007; Jalonen, 2011; Luthfa, 2017). Resource constraints make the transformation of an invention into innovation difficult (Kline and Rosenberg, 1986; Van de Ven et al., 1999; Gompers and Lerner, 2001; Powell and Grodal, 2005). Such uncertainties can create cognitive inertia among managers (Porac and Thomas, 1990; Eisenberg, 1995) leading to response uncertainty (McMullen and Shepherd, 2006). Under the condition of response uncer- 
tainty, one cannot calculate how to respond to a situation which is different from their anticipated reality.

\subsection{Sources of uncertainties in the innovation process}

One of the main sources of uncertainty is managers' lack of knowledge about the innovation process (Jalonen, 2011) that is how to recombine resources. Since novelty implies something new or significantly improved from the already available one, managers may not necessarily have complete information about how to recombine the resources or which resource recombination may bring the desired output. Under the condition of limited information, actors (hence, managers) experience cognitive limitation (Eisenberg, 1995); not knowing what to do or how to do. According to Eisenberg (1995) a cognitively limited actor is unduly optimistic; therefore, she tends to overlook necessary information to deal with a situation yet justifies her decisions or actions as rational under that condition. If managers overlook necessary information during the innovation process that may cause technological uncertainty by creating difficulties during resource recombination and eventually may lead to further uncertainties along the process.

Some other studies (e.g., Baraldi, et al., 2001; Fonseca, 2001; Håkansson and Waluszewski, 2002; Nerkar and Shane, 2003; Waluszewski, 2004; Baraldi and Strömsten, 2006; Hoholm and Olsen, 2012; Alexis, 2014) indicated that a possible source of uncertainty is the resources' own conflicting properties. Resources (for example, raw materials, machinery, knowledge) are heterogeneous (Penrose, 1959). When heterogeneous resources are combined they can create resistance to one another during integration. For example, if different types of components with different configurations are integrated they may create resistance to one another or when new views are incorporated traditional practices may create resistance and managers may find it difficult to come to consensus about how to handle the process. Due to resistance in resource combination it is possible that a great deal of friction will occur when new resources will be integrated in an existing resource base (Waluszewski, 2004). However, it is not known to what extent the frictions, tensions, or resistance encountered during the resource combination will stabilizes or destabilizes the resource bases and thus will affect efficient linking of later activities in the innovation process. According to Waluszewski (2004) the outcome of the resource recombination is "never given". Despite the indication that uncertainty in the innovation process may arise from the conflicting properties of resources and their combination, it is not substantiated in the existing research. According to some authors, a resource-recombination perspective needs more attention for a better understanding of the innovation process as well as to know if they have any impact on the emergence of uncertainties in the innovation process (e.g., Arthur, 2007; Petruzzelli and Savino, 2014).

Since activities constitute the basis of the innovation process (cf. Rogers, 1967; Richardson, 1972), logically unsuccessful coordination of the activities may give rise to uncertainties. According to Dubois (1994) every activity undertaken and coordinated in a process produces an output, which is used as an input for the next activity in the same process. In a process a future activity is dependent on the outcome produced from the previous activity (Thompson, 1967; Lundgren, 1995; Dubois, 1994; Håkansson et al., 2009; Bankvall, 2011). However, Dubois does not explain what happens in the activity chain in a process if an activity fails to produce a desi- 
rable outcome. Since activities are path dependent (Arthur, 1994; Lundgren, 1995; David, 2000; Sydow, et al., 2009) it is logical to argue that a single error in one activity in a process may lead to errors in ensuing activities in the same process. A failure in an activity may therefore hinders the production of the desirable outcome, unless an alternative path of activities can be created, or the iteration of a previously failed activity can produce a promising outcome. However, to what extent path-dependency of activities can create uncertainties in the innovation process is insufficiently considered in the literature.

\subsection{How uncertainty emerges in the innovation process - what has been discussed in the literature and what needs further attention}

Emergence of uncertainty is not a one-time phenomenon but rather it manifests itself or emerges throughout the innovation process over time (Fleming, 2001; Lenfle and Loch, 2010; Jalonen, 2011; Håkansson and Olsen, 2012; Rehn and Lindahl, 2012). Therefore, understanding of how uncertainties emerge in the innovation process lies in our understanding of how the process unfolds over time.

As defined earlier, innovation process entails some interconnected resource recombination activities over time (Schumpeter, 1934; Rogers, 1967; Richardson, 1972; Dubois, 1994; Rescher, 2000). However, the activities are not independent of the actors who undertake them (Rip, 2012) just as our actions are not independent of us (Luthfa, 2017). According to Rip (2012; p. 160) "actors and activities are mutually dependent". The activities are also not independent of the resources because one cannot undertake the resource recombination activities without the resources (Håkansson, 1987). According to Schumpeter (1934), resources are the central element for the novelty creation. The resources contribute to the creation of new resources as well as to the creation of novelties when they are combined through undertaking specific activities (Waluszewski, 2004). Furthermore, resources are not independent of the actors who control them and exploit them through undertaking the activities (Håkansson, 1987). The actors interact with other actors in a network context to gain control of the resources and to be able to exploit or recombine them through interactions (Drucker, 1985; Powell et. al., 1996; Etzkowitz and Leydesdorff, 2000; Pittaway et al., 2004; Lundvall and Nielsen, 2007; Håkansson et al. 2009; Tsai, 2009; Antikainen, Mäkipää, and Ahonen, 2010; Aune and Gressetvold, 2011; Perks and Moxey, 2011; Håkansson and Olsen, 2012). Thus, just as much the activities are inseparable for the actors who undertake them, resources are also inseparable from the actors who control and exploit them (Håkansson, 1987). This makes activities and resources as well as actors and resources mutually dependent. Therefore, to create knowledge about the innovation process it is important to consider the interrelation and interaction among the actors who undertake the resource recombination activities in a network context, activities which are undertaken by the actors who control and recombine the resources and the resources which are recombined for novelty creation by those actors.

Then again, due to mutual dependency among the actors, activities, and resources, the courses of action in an innovation process are affected not only by the actors who undertake or control them but also by the successful or unsuccessful activities of integrating and transforming the necessary resources into novelty. Furthermore, Rip argues (2012, p.158) innovation process is part of larger processes, and are entangled with organizations in a network, other technologies, 
sector dynamics, and societal responses. Due to the entanglement of different actors in a network context as well as their different levels of interactions for resources to undertake the activities, new events emerge continuously in the process. Emergence of new events lead to creation of new paths (new sequences of activities) as well as to creation of new actors (Lundvall, 1995) and new levels of interactions among them (Rescher, 2000; Rip, 2012). Due to so many different levels of interactions it becomes difficult for a single actor to control, steer, or plan the innovation process in advance (Lenfle and Loch, 2010; Håkansson and Olsen, 2012) that is, lead actors to uncertainty.

So far innovation processes have been studied either from the perspective of activities (for example, Bush, 1945; Anthony and Day, 1952; Maclaurin, 1955; Ruttan, 1959; Rogers, 1967; Kline and Rosenberg, 1986; Rothwell and Dodgson, 1992; Hobday, 2005; Godin, 2006) or from the perspective of actors (Etzkowitz and Leydesdorff, 2000; Edquist, 2005; Hobday, 2005; Lundvall, 2007) or from the perspective of resources (Fonseca, 2001; Petruzzelli and Savino, 2014) however not from an integrated perspective. This paper offers to create knowledge of the innovation process and how uncertainties emerge in the process by integrating these three different perspectives.

Håkansson's (1987) ARA model (Actor-Resource-Activity model) model illustrates the different layers of complexity involved in the interactive process of business among actors, resources and activities, thereby highlighting the complexities involved in the interactive process like innovation. However, the ARA model cannot explain how exchanged resources among the actors are utilized for production such as transformed from one form to another in a chain of transformation. The ARA model thus cannot explain how novelty is created in an innovation process. Dubois' (1994) "the end-product related activity structure model" complements the ARA model by illustrating how sequence of activities take place in a process, how outputs are produced from the activities and how the final outcome is produced at the end of the process. According to Dubois' model, output from an activity creates the basis for linking and coordinating the next activity in the chain. Thus, this model has great potential to create knowledge of how novelty is created at the end of a sequence of activities, which represent the innovation process. However, both the ARA model and the end-product related activity structure model assume that resources are available, if not available in house, from network of partners for undertaking activities when several studies showed the opposite result (e.g. Van de Ven et al., 1999; Holmen, 2001, Spencer, 2003; Ortt and Smits, 2006; Chaturvedi, et al., 2009; Muller, 2013). Both models are limited in explaining the consequences of resource unavailability on the activity undertaking thus are limited in explaining uncertainty in the process. The limitation in these two models can be complemented by integrating the project management literature (the Critical Chain Concept) which has the potential to explain how the activities can or cannot be undertaken in the innovation project if resources are not available (Goldratt, 1997). According to Goldratt (1997, p. 89) when resources are not available activity chain breaks in a process. Logically, if activity chain breaks actors may experience uncertainty. The project management literature can also be applied since the innovation process is often regulated under specific projects where numerous activities are undertaken sequentially over time and number of actors are involved. Accordingly, in the following section a conceptual model has been developed by integrating the ARA model, the end product related activity structure model and the theory of constraints to study how innovation 
process unfolds over time and at the same time to understand how uncertainties emerge in the innovation process.

\section{Theoretical model}

The conceptual model has been developed in this paper by integrating three models: the ARA model (Håkansson, 1987) and the end-product related activity structure model (Dubois, 1994) of the IMP school (Industrial Marketing and Purchasing) of the Uppsala University and the theory of constraints (Goldratt, 1997). The resulting model is called the uncertainty-embedded innovation process model (see figure 1).

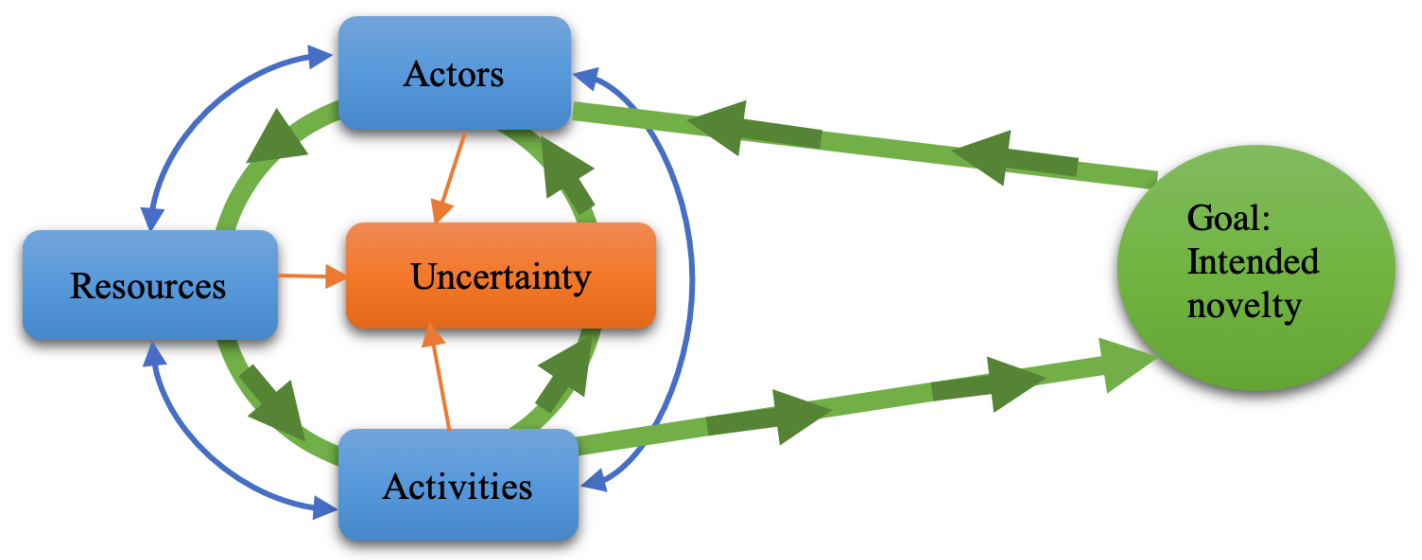

Fig. 1. The uncertainty-embedded innovation process model (Author's own)

The model (figure 1) depicts how an innovation process progresses over time in continuous interaction among actors, activities, and resources and the goal. The green arrows and path represent the interaction among actors, activities, and resources and the goal. The innovation process begins with an idea of creating a novelty (Rogers, 1983) which is represented by the goal in this model. The goal can be generated in the market by users' demand, or by the policy developed by the policy makers, or from the outcome of a scientific discovery (cf. Cyert and March, 1963; Rogers, 1983; Lundgren, 1995; Ingemansson, 2010). The goal guides the choices of resources, their combination, development of relationship with other actors and activities like research and development, production, commercialization, and diffusion (Rogers, 1967, 1983). The same goal limits the choices of resources, actors' activities and relationship with others (cf. Cyert and March, 1963; Gollwitzer and Moskowitz, 1996). However, due to entanglement of different actors in the innovation process (Drucker, 1985; Powell et. al., 1996; Etzkowitz and Leydesdorff, 2000; Pittaway et al., 2004; Lundvall and Nielsen, 2007; Håkansson and Olsen, 2012) and under the condition of limited information and knowledge (Knight, 1921; Reddy, 1996; Lenfle and Loch, 2010; Jalonen, 2011), no single actor can steer the innovation process as planned (Lenfle and Loch, 2010; Håkansson and Olsen, 2012). As the process advances over time, new events emerge in the innovation process; new resource combination takes place, new combining activities are undertaken, and new sources of resources appear which then shapes up 
the goal depending on the changes created from the previous interactions (cf. Rescher, 2000). An innovation process unfolds through dynamic interaction between the outcome of the process and the "holy trinity of a network" (Lundgren, 1995, p.93), i.e. the actors, activities, and resources as well as the reciprocity among them. In figure 1, reciprocity among the actors, resource and activities is represented by the blue double-sided arrows among the aspects.

Reciprocity among the three aspects, the actors, resources and activities, makes them selfreinforcing as well as make them affect each other in a negative manner in a cycle of cause and effect relationship. Any unconducive condition in any of these elements creates a negative impact on the other. For example, if actors fail to carry out an activity the failure may affect the outcome, which in turn may affect the linking of further activities in the chain. If an actor cannot explain the unconducive condition, based on its previous knowledge and experience of similar conditions, it cannot possibly fix the broken chain. Under such condition actors will experience uncertainty (cf. Knight, 1921). The orange arrows in the figure 1 show how uncertainty emerges as an outcome of the interaction among actors, activities, and resources. In the following, there is a list of some conditions when uncertainty may emerge in the innovation process:

1. Actors' are limited in cognition due to lack of knowledge of the detail of the technology, or due to undue optimism of having enough knowledge or information to deal with a problem therefore ignoring important information (Eisenberg, 1995). Actors limited cognition leads to uncertainty in the process as that hinders them from engaging the appropriate resources for undertaking the recombination activities.

2. Actors have conflicting expectations, and strategies for reaching the same goal (Cyert and March, 1963; Håkansson an Olsen, 2012). Their differences can evolve over time along with the changes of demands for resources and nature of activities they are undertaking together (Lundgren, 1995). If the differences sustain the process can proceed towards a different trajectory (cf. Rescher, 2000) than anticipated due to path dependency (Arthur, 2000). Differences can also lead to conflict, leading to breaching of trust (Morgan and Hunt, 1994; Nooteboom, Berger and Noorderhaven, 1997; Das and Teng, 1998; Madhok, 2006) and termination of relationships (cf. Izushi, 1997; Coles, 2003), thereby disrupt the resource flows among the partners and undertaking of the activities.

3. Resources are not always available either due to focal actors' inability to produce them, unwillingness of other actors to exchange necessary resources, by any institutional restriction, by the unsuccessful combination of differential and conflicting resources from previously undertaken activities (Goldratt, 1997; Fonseca, 2001; Gadde and Håkansson, 2001; Spencer, 2003; Håkansson and Walusewski, 2002; Waluszewski, 2004; Chaturvedi, et al., 2009; Hoholm and Olsen, 2012; Muller, 2013; Petruzzelli and Savino, 2014). Due to resource unavailability the linking of activities may become uncertain and eventually a condition called inertia can appear in the activity sequence (Goldratt, 1997).

4. Activities are path dependent (Lundgren, 1995). A firm's allocative decision made in the past limits and/or enable its decision in the present (Arthur, 1994; David, 2000; Sydow et al., 2009). An outcome of previously undertaken activities determines future activities, resources which are to be utilized and relationship which are to be nurtured. If the outcome is desirable the process may proceed smoothly, but if not, it may change an actor's courses 
of action that the one anticipated as well as can bring inertia in the process (Goldratt, 1997).

To sum up, uncertainty emerges in the innovation process under the aforementioned conditions prevailing in actors, activities, and resources.

\section{Methodology}

The unit of the analysis in this study is the innovation process - sequence of activities, and how they were undertaken and coordinated over time to produce a novelty. Study of the innovation process will also enable us to learn about how and why activities are not undertaken and linked that is, anomalies in the activity undertaking can tell us about the uncertainties under which activities could not be undertaken. The focus was given to the evidences which would tell about the various resource recombination activities performed and not performed, how the partner firms made resources available or were not willing to exchange resources and why, how the partners enabled and hinder activity undertaking of the focal firm and why, challenge regarding access to resources and how the actors solved those problems, and their roles in the process. A series of inquiry was performed, one leading to another until a coherent picture of the innovation process could be portrayed. Accordingly, number of people have been interviewed who were involved both directly and indirectly in undertaking different types of activities in the innovation process.

Innovation process unfolds over time. Therefore, to create knowledge of the innovation process it is important to tell a story in sequence of events. However, the sequence of events does not take place in a linear form but rather takes place in complex manner as the innovation process involves complex interaction among multiple actors, number of activities and various resources (Powell, et al., 1996; Edquist and Hommen, 1999; Pittaway, et al., 2004; Perks and Moxey, 2011). Among many of the benefits, a qualitative study offers the possibility of unfolding complex events over time through an in-depth narration (Kinnear and Taylor, 1996; Van de Ven and Poole, 2005; Marschan-Piekkarri and Welch, 2005; Silverman, 2013; Yin, 2014).

Initially, the theoretical understanding of the innovation process was not clear as a result the reality that has been encountered during data collection did not match with the theoretical map that has been developed from the existing theories. According to Easton (2000) this is often the reality that what we encounter do not always fit our mental map developed from our previous knowledge. Therefore, to develop new insight researchers need to move between the theory and reality over time in attempt to reduce the gap through several encounters. This approach is called the "systematic combining" (Dubois and Gadde, 2000). For facilitating the systematic combining approach, a case study has been designed which enables several encounters with the reality through intensive enquiry thereby enable refining the theoretical understanding gradually (Easton, 2010). The advantage of applying the case study is that when a gap is experienced between what one knows of the reality and the reality out there, one can go back to find answers to what happened the way it did over time through several encounters by returning for interviews. Another reason for choosing case study was its ability to deal with variety of data (Piekkari, et 
al., 2009) gathered from various sources, such as documents, artefacts, interviews, observations (Yin, 2014) thus could enable data triangulation (Yin, 2014).

Two case firms were selected from two different industries from two different countries with opposite economic conditions, business culture and institutional contexts. One company belongs to the industrial manufacturing industry and the other to the agricultural/biotechnology sector. The companies differ greatly in their product characteristics, production methods and contexts as well as demand different resources, actor involvement and nature of activities to perform innovation process. Furthermore, the companies were chosen from two countries from two different continents with opposite economic and political conditions, infrastructure, in hope of gaining interesting insight into the process. The underlying reason for choosing two disparate companies instead of two similar companies was that their differences would provide interesting insights into the innovation process, as they were more likely to exhibit different innovation process patterns, giving rise in different ways to uncertainties, than if they were from the same industry. Eisenhardt (1989) stated "creative insights often arise from the juxtaposition of contradictory or paradoxical evidence ... The process of reconciling these contradictions forces individuals to reframe perceptions into a new gestalt" (p. 546)." Moreover, one of the firms' innovation process exhibited a critical case. Its innovation story originated in a country where it faces high political instability, resource constraints and poor infrastructure. It was expected that the innovation process of this firm would exhibit patterns that would run counter to the existing theories and concepts (Patton, 2014) developed from observing companies in the developed countries thereby would allow the testing and refinement of existing theories (Emmel, 2013). Only two companies were selected as smaller number of cases, even a single case enables a researcher to deeply explore the research phenomenon (Mason, 2010; Easton, 2010; Patton, 2002). Furthermore, only two innovation stories from these two firms have been selected to take advantage of the possibility of detail observation and exploration of the phenomenon (Easton, 2000, Patton, 2014; Emmel, 2013; Yin, 2014) thus to be able to build an in-depth story into the innovation process. The selection criteria for choosing the case companies were that they should be undergoing or have undergone activities of innovation and should come from different contexts that is, they show disparity. The size of the firms was not considered as it was immaterial for fulfilling the purpose of the study. Initially, some companies were contacted from two countries based on their online profile. Companies which showed interest to take part in the process were selected for the data collection. Data collected from only two companies have been selected for the study.

Data were collected during 2013-2016 during the author's PhD research. The main means to collect data was face to face interview. On some occasions data were collected through phone calls and Skype interviews. Additional data, which had technical elements, were collected from scientific articles, $\mathrm{PhD}$ thesis, Youtube videos, Wikipedia, online brochure, newspaper articles, and direct observations. Interviewees were selected depending on their roles in the studied innovation processes. From the manufacturing company CEJN, the CEO, construction manager/engineering team, logistic manager, purchase manager, sales manager, assembly workers have been interviewed for their direct involvement in the innovation process. From the biotechnology company, the director of the agri-business, agricultural advisor, post-doctoral researcher, laboratory technician, and a researcher have been interviewed for their direct involvement in the innovation process. The data come from total 30 in-depth interviews, four field observations/factory visits, and email 
conversation. After each data-collection occasion (interviews) the data were transcribed. In one case the data needed to be translated as well from Bengali to English.

Initially, the data were not collected in the order in which the story has been told in the empirical section. After all the necessary data were collected, the data have been organized from beginning to end, keeping in mind the theoretical construct, to create a coherent picture of the innovation process (interaction among the actors, activities, and resources) and the uncertainties within it. Data have been analysed by applying the "pattern matching logic", where empirical patterns are compared with the conceptual model that the researcher formulated before data collection (Yin, 2014). During the analysis the theoretical model was used to see whether the reality fits to the model or not. When there was a fit, it was considered as a support for the theoretical argument and when there was no fit attempt has been made to explain why this was the case. At first within intra-case data analysis was done, and later a cross case analysis was done to reveal the similarities and differences among the cases to uncover certain patterns useful for refining and developing the theories.

During data collection I have faced some challenges, for example, the case companies did not allow me to interview their partners. As an Industrial Marketing and Purchasing researcher this was unsatisfactory. However, since activity links can also be studied from a single company's perspective (Bankvall, 2011), I collected data on the activities and their internal and external links (with the collaborators) from the case company's perspective. It was not possible to convince the respondents to answer all the questions for confidentiality, so I used the data that were obtainable. The credibility was ensured by sending the draft transcripts to the respondents after data transcription. I attempted to make analytical generalization of the data (Yin, 2014). The new understanding derived from the analysis could be used to reinterpret the cases in other context in the future. However, as researchers vary in their philosophies the same innovation process studied by other researchers in another context may exhibit different result. The study is dependable as the errors and biases have been removed by verifying the data with the respondents. Audit trail comprising raw data are available for inspection.

\section{Empirical data}

\subsection{Case 1: Innovation process of e-Safe by CEJN AB}

\section{History behind the e-Safe innovation}

When the Swiss government decided to ban the use and import of unsafe couplings in all industrial facilities in the country, followed by an accident in one of the factories in which a worker lost his hearing, the management were forced to bring a safer version of coupling called e-Safe. Although CEJN's engineers were aware that during coupling disconnection factory workers were at risk of injuring their eyes, eardrums, skin, and bones, even risks death, for them these risks were just theoretical, until the accident happened in the customer's facility. According to the construction manager Peter, "the accident was a major turning point for us; we realized something needed to be done ... we set the objective of creating a safety coupling for our customers". Therefore, CEJN made a quick market survey on customer's expectations of the safety coupling; its features or functions, their willingness to pay for a certain performance, size, and user-friendliness. During 
this time CEJN also convinced the Swiss authority to let its customers use the general quick coupling following the precautions asked by the government authority, until the safety coupling is developed and ready to be used.

\section{Commencing the project - Setting the objectives and Building the team}

In the head office the management set up an engineering team comprising of mechanical engineers, product designers and developers to commence the project. The management was very optimistic about the team's credibility therefore they felt no need to engage any external consultants. Peter, the construction manager said, "In teams, we consulted about the different parts of the general coupling, how they function, and specified mechanical difficulties of disconnection". A general coupling has two main parts, considered as a female and a male part, each part is connected to two different hoses or pipes or one hose and one piece of [hydraulic] equipment such as a blow gun. The two parts are connected through a latch. In a general coupling the latch lets the two parts separate from each other without much effort. The problem occurs when the male and female part disconnect from each other without much effort and their disconnection let high air/fluid pressure come out of the pipes abruptly as a result the pipes fly out of the hands of the workers. According to the CEO, "To prevent accidents we planned to develop e-Safe where male and female parts will be disconnected slowly. We decided to increase control over the latch by adding additional metal slots. A controlled latch would allow a slower disconnection of the male and the female parts from one another and in this manner would prevent kickback that causes the hoses to fly out of the workers' hands".

\section{Delegating the tasks, and Discussing the options}

Different groups were assigned to bring different designs. Evaluation of all the designs showed that integration of new and modified parts entailed changes in the exterior of the coupling, leading to increased weight and development cost. There was nothing more the team could do to prevent this change. According to the construction manager, Peter, "we wanted to hold the male part inside the female part for few more seconds before releasing it completely, and to do that we needed to add more components .... Our engineers suggested different configurations, all of which were good ... these would require a lot of work, a lot of adjustments of various components... we have to be rational ....we could not expect to make a major change for a simple fix in a simple function.....moreover, time was not in our favour... we knew we had to return to the market before someone else did."

\section{Facing the dilemma and making compromise}

Based on the chosen design among many others different parts were modified and a new part was developed. Some standardised activities were undertaken such as metals were cut, moulded in certain shapes, machined to produce the void inside the couplings and heat treated at extreme high and low temperatures for hardening, strengthening, and tempering and later on all parts were assembled. As anticipated the integration of the new and modified parts enhanced the size of the exterior and reduced the size of the interior however, the team did not expect that would reduce air flow inside the hoses. Safety assurance came at the cost of reduced performance. Although the solution was feasible in the eye of the engineers the customers were not very satisfied with the solution. Their dissatisfaction was reflected through their purchase decision According to the construction manager, "We had to consider the customers' expectations as well as the ban 
imposed by the Swiss government and the possible threat by our competitors ... we chose the option that in our opinion was the best in terms of safety, performance, cost effectiveness, and use-friendliness. To ensure the functionality that we wanted we had to forgo the space inside the coupling ... we had to compromise... The safety coupling was worse than the one we had before in terms of price, weight and performance but we achieved what we aimed for."

\section{Restarting the project for a sustainable solution -Lack of access to the desirable technology and inertia in the process}

After a while, the management realized that they needed to bring a sustainable solution because customers are not entirely satisfied with the new coupling. CEJN employed some new engineers who may have new insight into the matter. The new team noted that the safety coupling incorporated two components which need to be reduced into one to create space internally and to reduce the exterior. The team found out that there is a patented locking latch technology in the market which could be of use. However, the inventor, named Björn, refused CEJN's request. Peter said, "Having no access to the key technology we decided to ask our strategic suppliers to develop a locking latch for us but our suppliers lacked the Metal Injection Moulding technology (MIM) which is needed to build that latch. We also tried to find a similar technology in other parts of the world, but all efforts went in vain. We felt that we could not really go any further with the process. It was, somehow, a bit of vacuum without the right technology."

\section{Breaking the inertia - Access to the desirable technology and knowledge}

In 2010, Björn sold his patent to CEJN, when he could no longer run his small business. He showed willingness to help CEJN's team developing the safety coupling. Björn initially took part in the technology transfer process. During the first few meeting he showed the team how the key technology (locking latch) functions so that the team could integrate the latch properly in the existing coupling. There was not complete match of his latch with the current design so with much discussion and several attempts of trial and error along with Björn the team came up with an improved design of the new coupling called e-Safe. Major changes were made in the different body parts. After the prototype development in the warehouse the management decided to go for mass production of the latch by applying the MIM technology. They contacted a well reputed Chinese supplier who is skilled at using this technology.

\section{Latch development in collaboration with the Chinese supplier - Exchanging kno- wledge, repetitive failure, and compromises}

The team sent the design and the technical description of the latch to the supplier; dimension of the latch, needed harness of the materials, and the drawing. The team of CEJN and the supplier team had some discussions about the procedure, learn from each other about the safety coupling and the MIM technology. However, latch development took around 20 trials and errors before accepted by the team CEJN. Every time latches were developed as per the designs and measurement, they cracked under high air pressure. None of the team could understand what was wrong. The process was time consuming and not cost efficient. Peter said, "After a while, we realized that the supplier needed to see the complete design of the coupling so that they could have a complete understanding of the coupling. We had initially feared losing the IP but as the time was running out, this worry abated; the priority was to bring a solution to the Swiss market as quickly as possible. We felt that there was an information gap between us and the supplier. 
Although we were sceptical about revealing the whole design for fear of losing we realized that it was the right thing to do at that time". After getting access to the full design the supplier could see what was causing the problem accordingly, could solve the problem with little adjustment. Finally, after six months the new latch could be integrated in the existing general coupling in the main facility in Sweden. The customer is satisfied today. According to the CEO, "In the end, the final product design resulted from cooperation between the engineering team here and that of the supplier. Although the coupling now costs more, it is worth it".

\subsection{Case 2: Innovation process of Salinity Resistant High Yielding Wheat Seeds by ACI Ltd. Bangladesh}

\section{History behind the Salinity Resistant High Yielding Wheat Seeds innovation}

The initiative of developing this salinity resistant high yielding wheat variety (SRHYWS) was taken by the biotechnology and the agricultural division of a Bangladeshi company in 2012 in response to the government's "Food for all" policy and farmers' growing interest in cultivating staple food crop varieties. Although the country's agricultural researchers had long-term aspiration to solve the food insecurity problem but could not do much for a long time due to bureaucratic red tapes which hindered transferring of advanced technology from the developed countries for development of such seeds. According to the Executive director of the Agricultural business, "when the government encouraged such initiative, especially encouraged private companies to join in wheat research ACI Ltd. joined the race". Among all other crop varieties, the special focus was on wheat production because this crop has previously been paid less attention by farmers, despite its food value and potential to increase food security.

\section{Commencing the project - Setting the objectives and Building the team}

As an initial action to develop SRHYWS, ACI met with the countries' leading researchers in this area to decide on the technique they should use to develop this variety. Usually there are two ways to develop such seeds such as by using the chemical ethyl methane sulfonate (EMS) and gamma radiation. Researchers applied these methods earlier during 1974-76 and developed a stress tolerant wheat seeds called BARI Gom 25. This time the researchers wanted to develop a wheat variety by exploring the gene that carries the specific trait of salinity resistance, concentrating on that specific trait without disturbing the other genes through random radiation or chemical treatment. According to the advisor, "We needed to acquire knowledge of genetics of from experts to create newer genetic variation. So, I recommended ACI to collaborate with researchers from the developed countries." Accordingly, they contacted a professor at Lund University, Sweden, who applied a technique called the TILLING technique which is applied on crops for genetic modification through mutation.

\section{Delegating the tasks and Discussing the options}

In April 2012 ACI invited the professor and his team in Bangladesh. They visited the company, some public institutions, laboratory facilities in Bangladesh to get an idea about their potential collaborator. The team of the experts then discussed about how to start working on the project, how to look for funding for the project, how to write a proposal for funding, research strategy, long and short-term goals, milestones, technology transfer, human resources, accordingly signed an agreement. Both parties decided to share the expenditure of research and development in 
their respective countries accordingly signed an agreement. The parties also agreed to plant and harvest wheat during Swedish summer and Bangladeshi winter when the temperature is similar, to enhance the speed of the development process. However, since the Swedish professors lacked funding, ACI Ltd. agreed to help the professors to develop a strong funding application so that funding can be obtained from Swedish Research Council. In the meanwhile, Swedish team formally established a company OlsAro Crop Biotech $\mathrm{AB}$ and applied for funding with the help of the researchers in ACI Ltd. The goal of acquiring funding was to undertake the activities in Sweden, provide training to some researchers from ACI so that they can handle the activities efficiently, and have researcher exchange in between the countries.

\section{Beginning the actual R\&D work - Access to the key technology}

For the initiation of the project BARI Gom 25 was selected as the base variety because of its ability to resist stress to a certain extent. The first batch of seeds were called M1 variety and were treated with the chemical agent EMS using the TILLING technique in the Lund University laboratory in 2012. Theoretically, after treatment, the cells of the seeds will be mutated at DNA level and over time the seeds will exhibit the change through their production of crops. After the first EMS treatment the seeds were planted in the laboratory, crops were grown, harvested, seeds were collected, data on the seeds were gathered and sent to ACI to produce the third generation (M2 generation seeds). In ACI, the seeds were then planted, harvested, and seeds (M3 generation seeds) were collected following the same procedure that was undertaken in Sweden. With mutual consent 60 to 70 percent seeds were sent back to Sweden for next generation production (for M4 generation). While the process was still running smoothly OlsAro decided to test the seeds in an outdoor field by renting a land from a farmer's cooperative in Malmö without the consensus with ACI.

\section{Conflict among the parties on the way to handle the activities}

ACI was not happy with the decision to plant the seeds in the field since the Swedish collaborators lacked funding and human resource to support the production and monitoring in the field. The advisor said, "We were confident in the expertise of the researchers, trusted them, there was no reason to doubt their knowledge in this field, therefore, no necessity to discuss anything in detail about the process however, we expected them to inform us about this decision". In 2014 summer, the agricultural advisor of ACI visited Sweden to discuss the project's progress and he became highly dissatisfied when he found considerable amount of damages in the plants caused by birds/rabbits, and/or hares. His dissatisfaction increased when OlsAro asked for money from ACI for the field test, which was initially agreed to be carried out by the Swedish team. The advisor said, "Despite a great deal of dissatisfaction, we agreed to pay for the field test since it could not carry out the process on its own".

\section{Government restriction on resource transfer, breaching of trust and uncompromising actors}

When ACI agreed to transfer the money, it was restricted by the government policy in Bangladesh. According to the advisor, "It usually takes a long time to transfer money from Bangladesh to a foreign country. Government does not allow transfer over a certain amount of currency to other country." Due to the delay in transferring money from Bangladesh OlsAro denied sending M4 generation seeds to Bangladesh as a result ACI missed one planting season for six months. 
The tension was high between the parties at this time; ACI became sceptical about OlsAro's commitment and OlsAro losts its trust on ACI. After a while the communication had stopped completely and today the two companies are running R\&D in their respective countries. However, ACI was finally able to pay half of the research cost in Sweden as promised but they did not receive the seeds.

\section{Re-evaluating alternatives, restarting the project, involvement of the local actors and compromised goal}

After skipping a season, ACI decided to use the older generation seeds (M2 seeds) which they had in their laboratory. With much scepticism, due to lack of expertise, ACI started the project again. According to the advisor, "We engaged some local researchers to undertake the activities in the laboratory. They planted the seeds, harvested the crops, and collected a new generation seeds called M3. We sought for expert helps from the public research institutes and with the help of a public university (BAMRAU) we planted M3 generation seeds in the field. We ran further experiment in our green house by planting these seeds under high saline condition. We failed to get high salinity resistant seeds, but we found 17 lines of healthy green plants with much higher yields than those conducted before following the routine activities. Finally, we decided to go on pursuing high yield, since it as one of the properties the Bangladeshi government asked for. However, we have not yet given up hope of finding a salinity-resistant wheat, it may take a longer time... wish we could maintain the collaboration with the Swedish researchers, we could have found that trait in the wheat too."

\section{Analysis}

\subsection{Innovation of e-Safe}

\section{Conditions under which uncertainty emerged during the first attempt to produce e-Safe}

During the first attempt to create the new safety coupling uncertainties manifested themselves due to (1) complexities of the physical resource configuration (i.e. interconnectedness), (2) the unavailability of an important component or resources and (3) the actors' lack of knowledge of how to address the complexities.

1. The evidence from the safety coupling development reflects the existing theoretical explanations (cf. Baraldi, 2001; Fonseca, 2001; Håkansson and Waluszewski, 2002, Waluszewski, 2004; Petruzelli and Savino, 2014) which suggest that uncertainty can arise when an existing resource combination creates resistance against a new resource, with its internal resource interdependencies or interconnectedness. Such uncertainty could be resolved by recreating the interdependencies in the existing resource combination, however, CEJN's engineers did not have that knowledge.

2. During reconfiguration engineers failed to reduce the size of the exterior and increase the interior. That is, absence of the right type of latch led to some failed activities, although attempted. Data furthermore showed that due to lack of the right kind of latch, engineers 
had to forgo the expectation of fixing the air flow performance in the coupling, that is, they had to forgo the expectation of undertaking a certain activity relevant for the innovation of the e-Safe. This created uncertainty by creating a void in the activity chain.

3. Their lack of knowledge (resource) led to lack of understanding of what activities to undertake and how to recreate the interdependency. Thus, the three conditions affect one another and create conducive environment for uncertainty emergence. However, data shows that the engineers did not acknowledge their knowledge deficiency or cognitive limitation because they were unduly optimistic about producing the desirable coupling on their own. Undue optimism can make actors reluctant to search for alternative information or encourage actors to rationally ignore the chances of discovering new knowledge for decision making (Eisenberg, 1995).

\section{Outcome from the conditions causing uncertainties in the innovation process and what existing theories can or cannot explain}

An activity void was created in the activity chain when a necessary resource was missing. According to the ARA model and the end product related activity structure model, resources activate activities (Håkansson, 1987); logically the unavailability of the resource/s hinders the activation of the activities. However, the IMP theorists do not explain what happens in the activity sequence in a process when resources are not available, as the basis of their theory indicates that resources are always available, even if not in house, at least through business relationship (Håkansson and Snehota, 1995). Here, the data questions the basic assumption of the ARA model and the activity structure model. For example, data show that due to absence of the desirable locking latch (resource) engineers could not reconfigure (activity) the coupling the way they expected.

Then again, according to the concept of path dependency (Arthur, 1994; David, 2000, Sydow, et al., 2009) one can expect that a void in the activity chain, that is, an absence of an activity [undertaking] should stop undertaking of the next activity in the chain. Data showed that when a void was created in a specific area in the activity chain, other activities in the process did not stop taking place. Here the data defy the path dependency concept. This result can be explained by Dubois (1994) "the end product related activity structure model" which shows that an activity chain in a process can be composed of different complementary and parallel layers of activity chains (Dubois, 1994). Data show that when an activity void occurred in an area of an activity chain, engineers decided to compromise that specific area of the activity chain (hence, the void) and continue with other activities which can be complementary to the activity which created the void. Their decision led the process to concentrate on other activity undertaking thus forced the process towards a different trajectory producing a different outcome than expected. Here the data follow the path dependency concept where it argues that a change in previously undertaken activities in a process can force the process into different trajectory (Arthur, 1994; David, 2000, Sydow, et al., 2009). Then again, the decision to compromise the void instead of filling it up with trial and error led to further uncertainties when the customers did not prefer the outcome. 


\section{Conditions under which uncertainty emerged during the second attempt to produce e-Safe}

During the second attempt to create the new safety coupling (e-Safe) uncertainties manifested because of (1) the unavailability of the key technology (resource) caused by another actor's unwillingness to sell the key technology and (2) the unavailability of the key technology (resource) caused by failed attempt to create key resource.

1. Several studies demonstrate that a key cause of resource unavailability in the innovation process is linked to IP rights and actor's preferences not to cede patent to others (Chaturvedi, et al., 2009; Eveleens, 2010). CEJN acted on its best judgment (rationally considered) to maximize its own utility (by not showing the IP) but that action was in fact irrational because it created cognitive limitation in supplier by limiting necessary information and knowledge (Eisenberg, 1995). Thus, a certain activity undertaken by an actor can create cognitive limitation in another actor thus can affect the latter's ability to undertake important activities.

2. Data also showed that resource void was created from the failed output (resource) from the repeatedly failed planned activities under well-established method. The Chinese supplier was trying to develop the latch according to the specifications provided by CEJN by applying the MIM technology, with all the necessary materials (resources) in house, and design of the coupling (resources) yet the supplier failed to produce the desired component around 20 times. Inaccessibility to certain parts of the information (design) hindered the supplier from comprehending the complete measurement of the coupling as a result hinders them from developing the latch on time.

Outcome from the conditions causing uncertainties in the innovation process and what existing theories can or cannot explain

Trust played significant role on actors' willingness to exchange information and different types of resources in this case (Håkansson and Snehota, 1995; Madhok, 2006). The data shows that at the end after several failures CEJN realized that they had no choice but to trust the supplier with the complete design of the coupling. This implies that dependency or vulnerability for resources may promote trust development among actors (Luthfa, 2011). In this case CEJN's decision to extend trust was made rationally as CEJN was vulnerable in the relationship. Furthermore, we see that at the end the engineers did not compromise the void in the activity chain instead they continued to fill the void with repeated activities (trials and errors) until they could reach the desirable latch. The engineers here followed the planned activity chain and the goal. It shows that in the second phase of the development of the e-Safe the team followed a linear activity chain to develop a novelty that is the team did not try other routes to reach the output by making compromises in the process. As a result, we see that the process reached the outcome without deviation from the expected goal. 


\title{
6.2 Innovation of Salinity Resistant High Yielding Wheat Variety seeds - conditions under which uncertainty emerged
}

\author{
Conditions under which uncertainty emerged during the innovation of SRHYWV \\ seeds
}

Uncertainty emerged in the SRHYWV mainly because of (1) the differences among the actors about how they should handle the process based on their best judgment of utility maximization and (2) resource unavailability due to actors' unwillingness to share the resources due to breach of trust and (3) actors' limited cognition about how to undertake the activities.

1. According to the theory when actors differ in their activity handling, opinions, and expectations (Cyert and March, 1963; Holmen, 2001; Håkansson and Olsen, 2012) their differences can significantly affect their commitment in the relationship by diminishing trust (Morgan and Hunt, 1994; Nooteboom, Berger and Noorderhaven, 1997; Das and Teng, 1998). Data show that there were number of disagreements between the actors in the later phases of the process, for example, where to plant the seeds, who to bear the expenditure, how to handle the process and so on. Although initially ACI trusted their partner therefore were not concerned about how the process was handled by the other later their undue optimism that their partner is acting as planned and expected turned into fear that the partner is being opportunistic when the signed agreement was breached.

2. There disagreements led to conflicts and conflicts led them to not to trust the other. Lack of trust among the partners lead to poor exchange relationship (Madhok, 2006) as well as lead to termination of relationship (cf. Arias, 1995; Izushi, 1997; Coles, et al., 2003). When actors in a relationship feel that the other is opportunistic that hampers proper interactions among them, discourages commitments and trust, and eventually weaken relationship (Wilson and Jantaria, 1998). Data shows that in the later phases they lost trust on each other, they considered their opinion in the matter of production to be rationally driven based on their experiences and education and both acted accordingly without having the consent of the other. Their rational acts led them to termination of the relationship as a result ACI did not get access to the seeds which were to be sent by OlsAro. Without the seeds ACI missed a season and could not continue the process to develop the seed variety.

3. When ACI had to terminate the relationship with OlsAro, they faced deep uncertainty not knowing how to proceed with the process. Their limitation in cognition came from their lack of knowledge and expertise in the relevant field. Then again, their limited cognition drove them to gain access to other expertise which could enable them to sustain the process with compromised goals.

Outcome from the conditions causing uncertainties in the innovation process and what existing theories can or cannot explain

This result suggests that when both actors are rationally driven in a relationship and therefore not adaptive for the greater benefit the outcome of their interaction can in fact reflects actors' irrational behaviour or cognitive limitations. This result therefore emphasises the importance of being adaptive in partnership (Håkansson and Snehota, 1995; Gummesson, 2002) or being boundedly rational (Simon, 1955) in interaction with others that is being compromising. Furthermore, 
in SRHYWV innovation, resource unavailability (financial support) was created by the external actor (government) who was not directly involved in the process. The government affected the interaction between the parties with a constraining policy. In this case a void was created in the activity chain for six months by the act of the government which prohibited the exchange of certain resources among the actors (Freeman, 1974; Rogers, 1983; Nelson, 1993; Foster, 2010). Furthermore, we see that although initially the actors did not try to eliminate the void by undertaking other activities in parallel, later they realized that they should continue to undertake the activities they could. The act of compromise in the activity chain reduced the possibility of achieving the goal of producing the salinity resistance seeds.

\subsection{Cross case analysis - The conditions under which uncertainties emerged in the innovation process}

\section{Resource unavailability/void}

The data showed that in both cases uncertainty started because of resource unavailability which again was caused by actors' limited cognition (lack of knowledge and necessary information, undue optimism, rationally justified activities) to develop the necessary resources (Eisenberg, 1995) as well as by failed activities of resource combination. For example, CEJN's engineers did not have the knowledge of developing the hose pipe technology, ACI did not have the knowledge of TILLING techniques. CEJN's engineers were optimistic that they would be able to produce the locking latch without anyone's help therefore ignored the opportunity of getting help from someone (consultant) knowledgeable. ACI was strictly focused on the contract instead of looking at the benefits they could accrue from making somewhat adaptation to their partner's expectations. Resource unavailability was caused by external actor's (state) prohibition to resource exchange in case of SRHYWS. A probable reason is institutional differences among countries, which allowed the external actor to play such role on creating resource unavailability in the process in the case of SRHYWS. On safety coupling innovation the negative effect of the institutional differences was not observed. In the case of e-Safe resource unavailability was caused by conflicting properties of the resources which however is not noticeable in the case of SRHYWS due to the nature of the products.

\section{Activity void/limitation}

In both cases it is evident that resource unavailability (void) led to a condition called activity void. In this paper, activity void is considered as a condition when the activity which is necessary for producing novelty does not take place as a result no desirable output is produced. In another word activity void is a condition when possibilities of undertaking the necessary activities are limited due to limited resources and/or actors' limited cognition. Data show that when actors experience resource unavailability they reached the activity void. When they reached activity void they compromised some activities that is instead of undertaking the planned activities they undertook some other activities which could be supported by available resources and existing expertise and knowledge. For example, in the first phase of e-Safe development CEJN let go of the possibility of increasing the interior and reducing the exterior of the coupling since they had no knowledge of how to undertake the necessary adjustment activities. The outcome (the coupling) 
was rejected by the customers and it created uncertainty in the marketing of the coupling. In case of ACI the researchers let go of the possibility of bringing in the salinity resistant properties in the seed as planned and instead they continued to undertake other experiments which they could support with their available resources and expertise. As a result, they had to forgo an important property in the seeds (salinity resistance).

\section{Actor's cognitive limitation and trust in the relationship}

In both cases actors' limited cognition played an important role in creating uncertainties in the innovation process. CEJN's cognitive limitation led to lack of understanding of what activities to undertake and how to recreate the interdependency in its first attempt to develop the e-Safe. ACI's cognitive limitation led to lack of understanding and significant uncertainty about how to develop the SRHYWV seeds. In both cases trust was a significant issue behind resource unavailability. However, in case of safety coupling innovation actors' vulnerability lead to extension of trust among them and in case of SRHYWS vulnerability discourages trust development. Thus, data shows that trust among actors plays an important role behind the innovation process. It is presented in the data that when trust was extended by the actors, actors were more willing to exchange important resources which again enabled actors undertaking necessary activities on time in comparison with the situation when actors were not encouraged to extend trust in the relationship. However, trust does not reduce void in the activity chain directly, but it encourages actors to engage in beneficial exchange relationship which in turn enable undertaking of the activities in the process.

To sum up, based on the data one can argue that when an innovator compromises planned activities in an activity void, the innovator needs to accept that the process can move towards a different trajectory as path leads to paths (Arthur, 2000) thereby can increase further uncertainty by producing an undesirable outcome. Here the innovator's dilemma is whether to compromise the activities in the activity chain to reduce the void and continue with parallel activities or to fill up the void by undertaking the planned activities as long as it takes and delay the market penetration.

The following table 1 shows the conditions under which uncertainties emerged in the innovation process. Some of the conditions under which uncertainties emerge placed in the columns. Some of these conditions have been observed in both cases and some have not been observed. The conditions are resource void, actors' limited cognition (lack of knowledge, undue optimism leading towards over confidence, lack of adaptability in the relationship, lack of trust) and activity void. Resource void initially led the activity chain to an activity void, when no activity took place and later led to failed activities and undertaking of unplanned activities as actors compromised their planned activities. Due to compromises made in the activity chain undesirable outcomes were produced which again led to further uncertainties.

The following model, summaries how uncertainty emerged in both cases despite differences in their product characteristics, production method and industrial affiliation. The model shows that in both cases uncertainty emerged in interaction among actors' cognitive limitation, resource void and activity void, each leading the other over time as the process progressed towards reaching the goal. 
Table 1. Conditions under which uncertainties emerged in the innovation process of e-Safe and SRHYWV seeds

\begin{tabular}{llll}
\hline \multicolumn{2}{l}{ Conditions causing uncertainties } & $\begin{array}{l}\text { Safety coupling } \\
\text { innovation } \\
(\text { e-Safe })\end{array}$ & $\begin{array}{l}\text { Salinity resistant } \\
\text { wheat seed }\end{array}$ \\
\hline Resource void & Resource unavailability & Observed & Observed \\
\cline { 2 - 4 } & Resources' conflicting properties & Observed & Not observed \\
\hline \multirow{3}{*}{$\begin{array}{l}\text { Actors' limited } \\
\text { cognition }\end{array}$} & Lack of knowledge, expertise & Observed & Observed \\
\cline { 2 - 4 } & Undue optimism & Observed & Observed \\
\cline { 2 - 4 } & Lack of adaptability & Not observed & Observed \\
\cline { 2 - 4 } Activity void & Lack of trust & Observed & Observed \\
& $\begin{array}{l}\text { Failed planned/desirable } \\
\text { activities }\end{array}$ & Observed & Not observed \\
\cline { 2 - 4 } & Unplanned activities & Observed & Observed \\
\hline
\end{tabular}

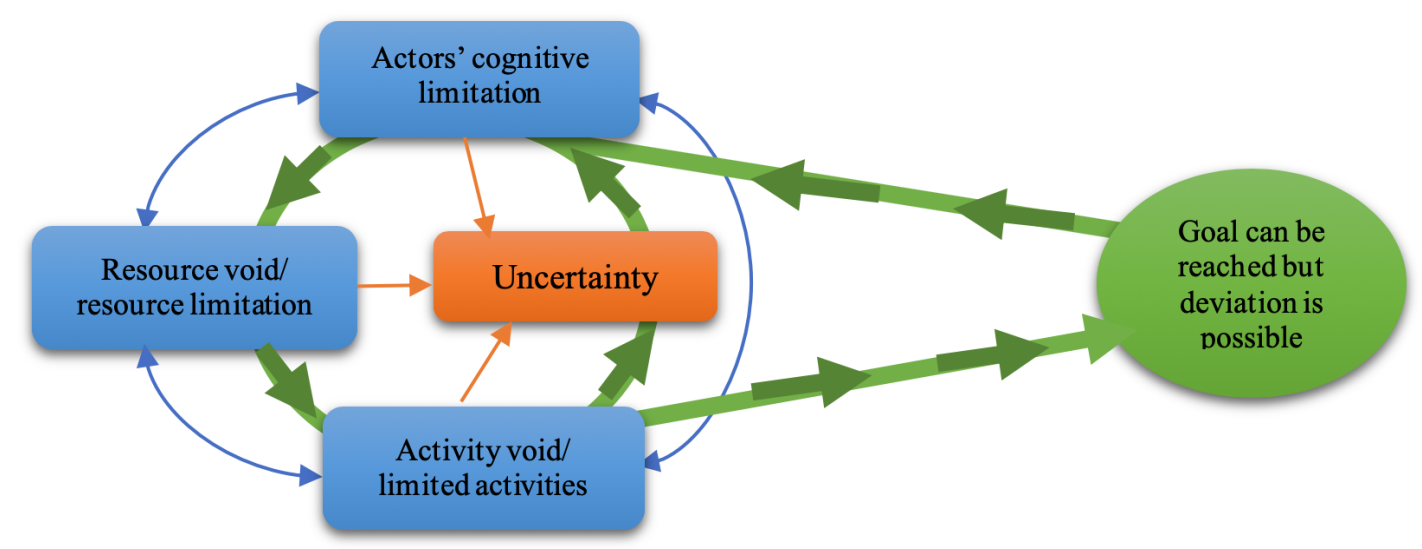

Fig. 2. How uncertainty emerged in the innovation process of e-Safe and SRHYWS (based on the analysis)

\section{Conclusion}

Uncertainty emerges in the innovation process of e-Safe and SRHYWV seeds because of actors' limited cognition, resource void and activity void, and the interaction among these three interdependent aspects. Actors are limited in cognition because they do not always have access to complete knowledge or information about what kinds of activities to be undertaken or what resources to be utilized, that is, actors always experience a resource void. Yet the actors can be unduly optimistic; considering they have adequate knowledge to handle certain activities. Unduly optimistic actors tend to disregard important information necessary for resource development and create further resource void in the process. When resource void appears due to 
unavailability of certain resources, the activities which demand those resources cannot be undertaken and coordinated thus, resource void creates activity void in the process and disturbs the activity chain. Alternately, when activity void appears, no desirable resources can be produced to undertake the next activity in the sequence thus activity void creates further resource void. Under such circumstances actors experience further cognitive limitation, as their existing understanding of how to eliminate the resource void by gaining access to the right resources or to eliminate the activity void by means of undertaking the right activities falls short. Actors with limited cognition can act in two ways; (1) they can prefer to be boundedly rational therefore can decide to forgo the expectation of filling up the voids by undertaking the planned activities with the desirable resources. The cost of such act of compromise is that the process may take a different trajectory than anticipated thereby can produce an undesirable outcome. (2) They can consider being rational therefore can decide to try to fill up the voids by undertaking the planned activities with the desirable resources. The cost of not compromising is that the process may take a longer time to reach the final outcome thus can have difficulties penetrating the market before the competitors. Here is a dilemma that an actor faces during the innovation process and this creates further limitation in actors' cognition to steer the process. Thus, uncertainty emerges in the innovation process in a cycle of interaction among resource void, activity void and actors' limited cognition.

The idea of being risk averse (Cyert and March, 1963) completely fails when it comes to the innovation process because uncertainties are embedded in the innovation process thus unavoidable. This paper suggests that a manger who is undertaking an innovation process should be willing to face this unavoidable and deal with it. The innovation process calls managers to be proactive risk takers instead of being risk averse and passive. Furthermore, the managers have to accept that they cannot act in completely rational manner but rather they have to be boundedly rational; act with certain extent of compromises when needed. Being too rational in the innovation process may lead to conflict with other actors as well as can delay the market entry by delaying the undertaking of the development activities. Therefore, managers are suggested to make necessary compromises to avoid falling into the activity void. Innovation projects are often so resource consuming that falling into the activity void can be common, though not an ideal situation. The paper further suggests that managers should look at the priority list and forgo achieving the overarching goal which may cost a fortune if fails, especially when resources are not promised. Nevertheless, the aim of the compromises should be achieving the best possible outcome from the best possible combination of resource combination by coordinating activities in the best possible way under the limited condition of resources. Although being compromising is motivated from the idea of being boundedly rational it is in fact motivated by a rational judgement.

While the paper attempts to contribute to the innovation management literature by integrating theoretical insights from the IMP perspectives, it questions the basic assumption of this perspective; resources are available, if not in the house at least through relationship development. The paper shows that gaining access to resources is not always possible even though relationship development is desired and embarked on. Furthermore, relationship development is not always preferable, even though lack of access to resources from potential partner can cost a great deal. Sometimes protecting one resource becomes so important that actors can forgo the opportu- 
nity of gaining other resources through relationship development. The IMP perspective cannot also explain a condition when activity cannot be linked or coordinated due to lack of resources. Although the IMP scholars argue that their approach enables investigation of the innovation process because of its ability to explain how resources are accessed and leveraged by partners (Gadde and Lind, 2016), this paper argues that they need to discuss the issue of resource unavailability which they have not touched upon so far. Since activity void has a significant impact on the innovation process, the paper suggests the IMP scholars to explain the implications of resource unavailability for activities in the innovation process so that our understanding of the innovation process can be improved.

To sum up, innovation process is interactive and moreover a boundary crossing interactive process (Waluszewski, et al., 2017). Firms interact with other firms across borders to acquire resources as well as to outsource activities. However, it is not always easy to acquire resources across border because there are significant differences among counties in terms of institutional policies supporting resource transfer (Luthfa, 2017). A firm's ability to acquire resources and to undertake the resource recombination activities become subject to the influence of the institutional differences across borders. Therefore, it is important to understand how firms from different institutional settings interact with one another for the purpose of novelty creation and how their interactions are affected by the institutional differences so that suggestions can be made for policy improvement.

The paper is limited in explaining how uncertainties emerge in the service sector innovation and open innovation sector. The study of the open innovation process could possibly enable us to understand how to eliminate resource void as well as activity void in the innovation process as firms are able to exploit the ideas and knowledge outside of their boundaries (Chesbrough, 2003). Therefore, it would be interesting to study open innovation process in relation to how to reduce activity void. Since activity void can have a serious impact on the innovation process as it hinders the undertaking and linking of the activities it would be useful to investigate this aspect in future research. Then again, since the activity void and resource void are interconnected one cannot separate their studies. The studies of activity-resource voids would contribute to the field of innovation operation management. The paper did not study innovation process undertaken by the start-up companies. Both companies were established and had enough resources to deal with the processes. Start-up companies face more difficulties than the established firms as they often lack financial resources (Muller, 2013). Financing difficulties are a common type of uncertainty in the innovation process for small start-up firms as a result many promising ideas fail to be realized (Luthfa, 2017). Future studies can also look into how uncertainties emerge in the start-up phases in the innovation process and how they can be managed efficiently.

\section{Acknowledgement}

I would like to pay my gratitude to Dr. Gabriela Schaad and two anonymous reviewers for sharing ideas, providing insights and suggestions for the improvement of the paper. 


\section{References}

Alexis, J. (2013). Design Innovation. In Gupta, P and Trusko, B. E. (Ed.), Global Innovation Science Handbook. New York: McGraw Hill.

Anthony, R. N. \& Day. J. S. (1952). Management Controls in Industrial Research organizations: Boston, Harvard University.

Antikainen, M., Mäkipää, M., \& Ahonen, M. (2010). Motivating and supporting collaboration in open innovation. European Journal of Innovation Management, 13(1), 100-119. doi: $10.1108 / 14601061011013258$

Arthur, W. B. (1994). Increasing returns and path dependence in the economy: University of Michigan Press.

Arthur, W. B. (2007). The structure of invention. Research Policy, 36(2), 274-287.

Aune, T. B., \& Gressetvold, E. (2011). Supplier Involvement in Innovation Processes: A Taxonomy. International Journal of Innovation Management, 15(01), 121-143. doi: 10.1142/s1363919611003106

Bankvall, L. (2011). Activity Linking in Industrial Networks. PhD Thesis, Chalmers Univeristy of Technology.

Baraldi, E., Bocconcelli, R., \& Söderlund, A. (2001). Resource Interaction in Furniture Networks. Relating Design, Distribution and IT, Nordiske Organisasjonsstudier, 3(4), 2001.

Baraldi, E., \& Strömsten, T. (2006). Embedding, producing and using low weight: Value creation and the role of the configuration of resource interfaces in the networks around Holmen's newsprint and IKEA's Lack table. IMP Journal, 1(1), 52-97.

Bessant, J. (2008). Dealing with discontinuous innovation: the European experience. International Journal of Technology Management, 42(1-2), 36-50.

Braeutigam, R. R. (1979). The Effect of Uncertainty in Regulatory Delay on the Rate of Innovation. Law and Contemporary Problems, 43(1), 98-111.

Bush, V. (1945). Science the endless frontier: North Stratford: Ayer Co., 1995.

Cantarello, S., Nosella, A., Petroni, G., \& Venturini, K. (2011). External technology sourcing: evidence from design-driven innovation. Management Decision, 49(6), 962-983.

Chaturvedi, M., Kumar, A and Rahul, M. (2009). Managing Innovation and New Product Development -Concepts and Cases. Eastern Academy Edition(ISBN: 9788120337275).

Chesbrough, H. W. (2003). Open Innovation: The new imperative for creating and profiting from technology. Boston: Harvard Business School Press.

Coles, A.-M., Harris, L., \& Dickson, K. (2003). Testing goodwill: conflict and cooperation in new product development networks. International Journal of Technology Management, 25(1), 51-64.

Cyert, R. M., and March, J. G. (1963). A Behavioral Theory of the Firm (Vol. 2nd). Englewood Cliffs, NJ: Prentice Hall. 
Damanpour, F. (1996). Organizational complexity and innovation: developing and testing multiple contingency models. Management Science, 42(5), 693-716.

Das, T. K. and Teng, B.S. (1998). 'Between trust and control: Developing confidence in partner cooperation in alliances', Academy of Management Review, 23 (3): 491-512.

David, P. A. (2000). Path dependence and varieties of learning in the evolution of technological practice. Paper presented at the Technological innovation as an evolutionary process.

Dodgson, M., Gann, David, M., Nelson, P. (2015). The Oxford Handbook of Innovation Management. Oxford UK: Oxford University Press.

Dosi, G. (1982). Technological Paradigms and technological trajectories. Research Policy, 11(3), 147-162.

Drucker, P. F. (1985). The discipline of innovation. Harvard Business Review, 63(3), 6772 .

Dubois, A. (1994). Organizing Industrial Activities - An Analytical Framework, Doctoral thesis, Chalmers University of Technology.

Dubois, A. \& Gadde, L.E. (2000). Supply strategy and network effects-purchasing behaviour in the construction industry. European Journal of Purchasing \&5 Supply Management, 6, 207215.

Easton, G. (2010). Critical realism in case study research. Industrial Marketing Management, $39(1), 118-128$.

Edquist, C., \& Hommen, L. (1999). Systems of innovation: theory and policy for the demand side. Technology in Society, 21, 63-79.

Eisenhardt, K. (1989). Building Theories from Case Study Research. Academy of Management Review, 14(4), 532-550.

Emmel, N. (2013). Sampling and Choosing Cases in Qualitative Research: A Realist Approach. Sage Publications.

Etzkowitz, H., \& Leydesdorff, L. (2000). The Dynamics of Innovation: From National Systems and "Mode 2" to a Tripple Helix of University-Industry-Government Relations. Research Policy, 29(2), 109-123.

Fleming, L. (2001). Recombinant uncertainty in technological search. Management Science, $47(1), 117-132$.

Fleurke, F., \& Somsen, H. (2011). Precautionary regulation of chemical risk: How REACH confronts the regulatory challenges of scale, uncertainty, complexity and innovation. Common Market L. Rev., 48, 357.

Fonseca, J. (2001). Complexity and Innovation in Organization. Routledge.

Foster, J. (2010). Productivity, creative destruction and innovation policy: Some implications from the Australian experience. Innovation, 12(3), 355-368. 
Freel, M. S. (2005). Patterns of innovation and skills in small firms. Technovation, 25(2), 123-134. doi: http://dx.doi.org/10.1016/S0166-4972(03)00082-8

Freeman, C. (1974). The Economics of Industrial Innovation. London: Frances Pinter.

Gadde, L.-E., \& Lind, F. (2016). Interactive resource development: implications for innovation policy. IMP Journal, 10(2). doi: 10.1108/IMP-08-2015-0043

Galbraith, J.K. (1977). The Age of Uncertainty Boston, Houghton Mifflin Company.

Gartner, W. B. (1990). What are we talking about when we talk about entrepreneurship? Journal of Business Venturing, 5(1), 15-28. doi: http://dx.doi.org/10.1016/0883-9026(90)90023$\mathrm{M}$

Godin, B. (2006). The Linear Model of Innovation: The Historical Construction of an Analytical Framework. Institut National de la Recherche Scientifique(4).

Goldratt, E. M. (1997). Crtical Chain. North River Press.

Gompers, P., \& L.erner, J. (2001). The Venture Capital Revolution. The Journal of Economic Perspectives, 15(2), 145-168.

Gummesson, E. (2002). Total Relationship marketing. Butterworth Heinemann, 2nd edition.

Håkansson, H., \& Olsen, P. I. (2012). Innovation management in networked economies.

Håkansson, H., \& Waluszewski, A. (2002). Managing Technological Development. IKEA, the environment and technology London, Routledge.

Hobday, M. (2005). Firm-level Innovation Models: Perspectives on Research in Developed and Developing Countries. Technology Analysis \& Strategic Management, 17(2), 121-146.

Hoholm, T., \& Olsen, P. I. (2012). The contrary forces of innovation: A conceptual model for studying networked innovation processes. Industrial Marketing Management, 41(2), 344-356. doi: http://dx.doi.org/10.1016/j.indmarman.2012.01.013

Holmen, E. (2002). Notes on a conceptualisation of resource-related embeddedness of interorganisational product development. . Dissertation, University of Southern Denmark. Sönderborg.

Hulthén, K. (2002). Variety in distribution networks: a transvection analysis: Chalmers tekniska högsk.

Izushi, H. (1997). Conflict between two industrial networks: technological adaptation and inter-firm relationships in the ceramics industry in Seto, Japan. Regional Studies, 31(2), 117129.

Jalonen, H. (2011). The uncertainty of innovation: a systematic review of the literature. Journal of Management Research, 4(1).

Kinnear, T. C., \& Taylor, J. R. (1996). Marketing Research. An Applied Approach. McGrawHill.

Kirzner, I. (1979). Perception, Opportunity, and Profit. Chicago: University of Chicago Press. 
Kline, S. J., \& Rosenberg, N. (1986). An overview of innovation. The positive sum strategy: Harnessing technology for economic growth, 275, 305.

Knight, F. H. (1921). Risk, Uncertainty and Profit: Beard Books Incorporated, Chevy Chase.

Lampela, H. (2012). Dynamics of development in innovation collaboration -relationships, learning and end products. International Journal of Innovation Management, 15(1/2).

Lenfle, S., \& Loch, C. (2010). Lost Roots: How Project Management Came to Emphasize Control Over Flexibility and Novelty. California Management Review, 53(1), 32-55.

Lundgren, A. (1995). Technological Innovation and Network Evolution: Thomson Learning.

Lundvall, B.-A., \& Nielsen, P. (2007). Knowledge management and innovation performance. International Journal of Manpower, 28(3/4), 207-223.

Lundvall, B. Å. (2007). National innovation systems - analytical concept and development tool. Industry and Innovation, 14 (1), 95-119.

Luthfa, S. (2017). The Uncertainty-Embedded Innovation Process - A study of how uncertainty emerges in the innovation process and of how firms address that to create novelty. Doctoral thesis, Halmstad University Press.

Luthfa, S. (2011). Tying Bonds - The facilitating and the constraining role of dyadic relationships on business development. Licentiate Thesis, University of Gothenburg.

Maclaurin, W. P. (1955). Innovation and Capital Formation in Some American Industries, in National Bureau of Economic Research, Capital Formation and Economic Growth. Princeton: Princeton University Press, 551-578.

Madhok, A. (2006). How much does ownership matter? Equity and trust in joint ventures, Journal of International Business Studies, 37(1), 4-11.

Marcus, A. A. (1981). Policy Uncertainty and Technological Innovation. Academy of Management Review, 6(3), 443-448.

Marschan-Piekkarri, R., \& Welch, C. (2005). Handbook Of Qualitative Research Methods For International Business. .

Martínez-Ruiz, T., García, F., \& Piattini, M. (2011). Managing process diversity by applying rationale management in variant rich processes. Paper presented at the International Conference on Product Focused Software Process Improvement.

Mason, M.(2010. Sample size and saturation in PhD studies using qualitative interviews. Forum: Qualitative Social Research.

McMullen, J. S., \& Shepherd, D. A. (2006). Entrepreneurial action and the role of uncertainty in the theory of the entrepreneur. Academy of Management Review, 31(1), 132-152.

Messeni Petruzzelli, A., \& Savino, T. (2014). Search, Recombination, and Innovation: Lessons from Haute Cuisine. Long Range Planning, 47(4), 224-238. doi: http://dx.doi.org/10.1016/j.lrp.2012.09.001 Milliken, F. J. (1987). Three Types of Perceived Uncertainty about the Environment: State, 
Effect, and Response Uncertainty. The Academy of Management Review, 12(1), 133-143. doi: $10.2307 / 257999$

Morgan, R. M. and Hunt, S. D. (1994). The commitment-trust theory of relationship marketing, Journal of Marketing, 58, 20-38.

Muller, R. A. (2013). Innovation and scientific funding. Science.

Nagati, H., \& Rebolledo, C. (2013). Supplier development efforts: The suppliers' point of view. Industrial Marketing Management, 42(2), 180-188. doi: http://dx.doi.org/10.1016/j.indmarman.2012.12.006

Nelson, R. R. (1993). National Innovation Systems: A Comparative Analysis New York: Oxford University Press.

Nerkar, A., \& Shane, S. (2003). When do start-ups that exploit patented academic knowledge survive? International Journal of Industrial Organization, 22(9), 1391-1410.

Nooteboom, B., Berger, H. and Noorderhaven, N. G. (1997). 'Effects of trust and governance on relational risk', Academy of Management Journal, 40, (2): 308-338.

Ortt, J. R., \& Smits, R. (2006). Innovation management: different approaches to cope with the same trends. International Journal of Technology Management, 34(3-4), 296-318.

Oslo manual (2005). The Measurement of Scientific and Technological Activties.

Patton, M. Q. (2014). Qualitative Research \& Evaluation Methods. Sage Publications, 4th Edition.

Patton. M. Q. (2002) Qualitative Research \& Evaluation Methods. Sage Publications.

Pavitt, K. (1983). Characteristics of innovative activities in British industry. Omega, 11(2), 113-130. doi: http://dx.doi.org/10.1016/0305-0483(83)90001-4

Pavitt, K. (2013). Innovation Processes. In J. Fagerberg, Mowery, David, C. and Nelson, Richard, R. (Ed.), The Oxford Handbook of Innovation. Oxford, UK: Oxford University Press.

Penrose, E. (1959). The Theory of the Growth of the Firm. Oxford University Press.

Perks, H., \& Moxey, S. (2011). Market-facing innovation networks: How lead firms partition tasks, share resources and develop capabilities. Industrial Marketing Management, 40(8), 12241237. doi: 10.1016/j.indmarman.2011.10.005

Pittaway, L., Robertson, M., Munir, K., Denyer, D., \& Neely, A. (2004). Networking and innovation: a systematic review of the evidence. International Journal of Management Reviews, 5(3-4), 137-168. doi: 10.1111/j.1460-8545.2004.00101.x

Porac, J. F., \& Thomas, H. (1990). Taxonomic mental models in competitor definition. Academy of Management Review, 15(2), 224-240.

Porter, M. E., \& Clark, G. L. (2000). Locations, clusters, and company strategy. The Oxford handbook of economic geography, 253-274.

Porter, M. E., \& Stern, S. (2001). Innovation: location matters. Mit Sloan Management Review, 42(4), 28. 
Powell, W. W., Koput, K. W., \& Smith-Doerr, L. (1996). Interorganizational Collaboration and the Locus of Innovation: Networks of Learning in Biotechnology. Administrative Science Quarterly, 41(1), 116-145. doi: 10.2307/2393988

Powell, W. W., Koput, K. W., \& Smith-Doerr, L. (1996). Interorganizational collaboration and the locus of innovation: Networks of learning in biotechnology. Administrative Science Quarterly, 116-145.

Prieger, J. E. (2007). Regulatory delay and the timing of product innovation. International Journal of Industrial Organization, 25(2), 219-236.

Reddy, S. G. (1996). Claims to expert knowledge and the subversion of democracy: The triumph of risk over uncertainty. Economy and Society, 25(2), 222-254.

Rehn, A., \& Lindahl, M. (2012). Muddling through in innovation-On incremental failure in developing an engine. Journal of Business Research, 65(6), 807-813.

Rescher, N. (2000). Process Metaphysics: An Introduction to Process Philosophy. State University of New York Press.

Richardson, G. B. (1972). The Organisation of Industry. The Economic Journal, 82(327), 883-896. doi: $10.2307 / 2230256$

Rip, A. (2012). The context of innovation journeys. Creativity and Innovation Management, $21(2), 158-170$.

Rogers, E. M. (1967). Diffussion of Innovations. The Free Press, McMillan Publishing Co., Inc. New York.

Rogers, E. M. (1983). Diffusion of innovations: Free Press ; Collier Macmillan.

Rothwell, R., \& Dodgson, M. (1991). External linkages and innovation in small and medium-sized enterprises. R\&D Management, 21(2), 125-138.

Ruttan, V. W. (1959). Usher and Schumpeter on Invention, Innovation, and Technological Change. The Quarterly Journal of Economics, 73(4), 596-606. doi: 10.2307/1884305

Silverman, D. (2013). Doing qualitative research: A practical handbook: SAGE Publications Limited.

Simon, H. A. (1957). Administrative behavior (Vol. 4): Free Press New York, NY.

Smith, K. (2005). Measuring innovation. In Fagerberg, J., Mowery, D.C \& Nelson, R. R. (Ed.) Oxford Handbook of Innovation (pp. 148-177): Oxford University Press, New York, US.

Spencer, J. W. (2003). Firms' knowledge-sharing strategies in the global innovation system: Empirical evidence from the flat panel display industry. Strategic Management Journal, 24(3), 217-233.

Sydow, J., Schreyögg, G., \& Koch, J. (2009). Organizational path dependence: Opening the black box. Academy of Management Review, 34(4), 689-709.

Thompson, J. D. (1967). Organizations in Action. (New York: McGraw-Hill.). 
Tidd, J. a. B., John. (2009). Managing innovation: Integrating technological, market, and organizational change. Chichester, England: John Wiley \& Sons.

Tsai, K.-H. (2009). Collaborative networks and product innovation performance: Toward a contingency perspective. Research Policy, 38(5), 765-778. doi: 10.1016/j.respol.2008.12.012

Utterback, J. M. \& Abernathy, W. J. (1975). A dynamic model of process,and product innovation. Omega, 33(639-656).

Van de Ven, A. H., Polley, D. E., Garud, R., \& Venkataraman, S. (1999). The innovation journey. Oxford University Press.

Wagner, S. M., \& Hoegl, M. (2006). Involving suppliers in product development: Insights from R\&D directors and project managers. Industrial Marketing Management, 35(8), 936-943. doi: 10.1016/j.indmarman.2005.10.009

Waluszewski, A. (2004). A competing or co-operating cluster or seven decades of combinatory resources? What's behind a prospering biotech valley? Scandinavian Journal of Management Studies, 20, 125-150.

Waluszewski, A., Baraldi, E., \& Perna, A. (2017). The role of policy in innovation: The challenging distribution of social, material and monetary benefits. IMP Journal, 11, 51-71.

Wilson, D.T. \& Jantrania, S. (1996). Understanding the value of a relationship, Asia Australia Marketing Journal, 2(1), 55-66.

Yamin, S., Mavondo, F., Gunasekaran, A., \& Sarros, J. C. (1997). A study of competitive strategy, organisational innovation and organisational performance among Australian manufacturing companies. International Journal of Production Economics, 52(1), 161-172.

Yin, R. K. (2014). Case Study Research: Design and Methods (Applied Social Research Methods. Sage Publications.

York, J. G. \& Venkataraman, S. (2010). The entrepreneur-environment nexus: Uncertainty, innovation, and allocation. Journal of Business Venturing, 25(5), 449-463. 
Journal of Innovation Management

Luthfa

JIM 7, 1 (2019) 46-79

\section{Biographies}

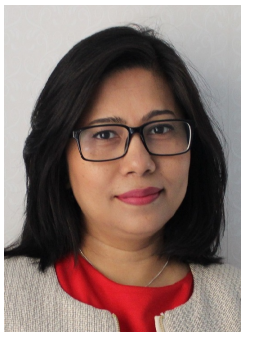

Sabrina Luthfa. Sabrina Luthfa is a Senior Lecturer in the Division of Business Administration, University of West, Sweden. 